\title{
Online Food for Brick and Mortar Retailers: State of the Art in Italy
}

\author{
Andrea Payaro, PhD and Anna Rita Papa
}

\begin{abstract}
In contemporary entrepreneurial environment based on customer retention, the growth of the internet has pushed the most dynamic businesses to compete in the electronic market. The recent evolvement of the Internet as a new major distribution channel has obtained much attention, as the online channel calls the viability of traditional stationary retailing into question. Today, since innovation is a key factor in the Digital Age, the presence in the digital marketplace is essential for retailers, also in the food retailing. The paper aims to analyze the online commerce for food groceries. The sample represents the $99 \%$ of Italian brands of brick and mortar supermarkets and hypermarket. Through the visit of every Internet site and some interviews to managers, this paper proposes the reasons why only a limited number of grocery brands sell food over Internet. Characteristics of goods (freshness, perishability, cold chain warranty, etc.), expensive operations needed to prepare the delivery, cost of delivery, and difficult reverse logistics are the main causes of low adoption of ecommerce. The few cases of food ecommerce offer product delivery only in a limited radius of certain big cities.
\end{abstract}

Keywords - brick and mortar, food grocery, e-commerce, product delivery.

\section{INTRODUCTION}

$\mathrm{T}$ HE number of Internet users has been steadily increasing all over the world, including developing countries. In Asia and Eastern Europe, Internet access rates were considerably high during the last year. In addition, more than 70 percent of the population has access to internet from home in Western Europe, North America, and Australia, and by 2016 the number will be closer to 80 percent in these regions. Ecommerce is big business and getting bigger every day. Retail sales worldwide - including both in-store and internet purchases - will reach $\$ 22,492$ trillion this year, according to new figures from eMarketer [1]. The global retail market will see steady growth over the next few years, and in 2018, worldwide retail sales will increase $5.5 \%$ to reach $\$ 28,300$ trillion. The most popular e-commerce categories, not surprisingly, are non-consumable-durables and entertainment-related products. Nielsen [2] reported that

Andrea Payaro, Ph.D. CEO P\&P Consulting \& Service, 35020 Legnaro PD - ITALY (corresponding author's phone: +39 349357 3434;

e-mail:andrea@pepconsulenze.it).

Anna Rita Papa, Researcher at P\&P Consulting \& Service, 35020 Legnaro PD - ITALY (corresponding author's e-mail: annarita@ pepconsulenze.it). almost half of global respondents in an online survey intend to purchase clothing or make airline or hotel reservations using an online device in the next six months [3]. Other categories growing in prominence for online shopping include e-books, event tickets, sporting goods, and toys [4].

The fast growth rate of the online grocery market presents a challenge for supermarket chains competing for share, in terms of balancing their online and offline investments. A better understanding of the triggers which influence the adoption (and the discontinuation) of online grocery shopping is vital for the strategic management of this sector, both in the "more developed" market and elsewhere.

Shopping for groceries online is arguably a discontinuous innovation [5], requiring a significant change in behavior [6]: online shoppers forfeit the social interaction of offline shopping and the potential to evaluate groceries prior to purchase. For online grocery shopping to develop beyond its current "niche" size, retailers need to understand not only what triggers consumers to change their purchase behavior, but also the extent to which their online shopping experience reinforces the adoption process.

Previous research pertaining to Internet grocery shopping has focused on comparing online and offline purchase behavior in terms, for instance, of brand loyalty [7], shopping behavior [8], the importance of brand names [9]; and consumers' perceptions of the advantages and disadvantages of shopping online for groceries [10]. Another important stream of research has examined the consumer traits of Internet shoppers, either in terms of their general shopping orientation [11], their web-usage-related lifestyle [12], or psychographic characteristics [13]. Additionally, Rohm and Swaminathan [14] developed a typology of internet grocery shoppers based upon their motivations for shopping online.

This paper aims to describe the state of the art of food online commerce for brick and click Italian supermarkets. Retailers use "Brick and Click" model when they can operate dual channels: traditional and on line [15]. The increase in online retail sales is influenced not only by pure players, but also brick-and-mortar companies that have taken in the opportunities of e-commerce and are implementing multichannel strategies (brick and click). It is clear that e-commerce has created opportunities for both small and large companies and a wide range of benefits for consumers as well [16].

Although online stores have many advantages (convenience, easy access to product and service information, twenty-four seven, tools for product and price comparison), 
they also have disadvantages over brick-and-mortar stores. One of the most important disadvantages is the fact that consumers cannot touch, feel, taste, or smell the products; this prevents consumers from assessing product quality and increases risk perceptions. People like buying in physical shops, preferring them in all the phases of the shopping journey we have just mentioned [17].

With Amazon.com entering the grocery channel, traditional grocery retail chains will have to face a new competitor who already owns the logistics and customer base. Amazon is soon expected to become the next giant in online food retailing. Supermarket giants Wal-Mart Stores and Kroger already draw sales from their online efforts and compete with Amazon and other e-commerce challengers, but the report from Food Marketing Institute and Nielsen points out that the online channel is likely to capture significantly more market share in the decade ahead from the bricks-and-mortar stores [18].

Some of the reasons why an increasing number of consumers buy groceries online are common to all Internet purchases, including better prices, larger selection, convenience, and time savings. Home delivery of items purchased online is appealing to those for whom going out to shop is difficult for various reasons, such as physical disability, the need to care for small children, the lack of adequate or convenient transportation, and/or a busy lifestyle. Buying groceries and other products online unchains consumers from physically driving to and shopping in traditional stores [19].

\section{MASS RETAIL MARKET IN ITALY}

In Italy, the food retail and distribution sector is fragmented. Traditional grocery stores continue to represent the majority share of the outlets, with few large retailers and many small local retail stores. Fortunately, consolidation is gaining momentum with Italian and foreign operators starting to expand their network of stores. Unlike other European nations, the Italian food retail and distribution sector continues to resist consolidation with small, traditional grocery stores (so-called Mom and Pop stores) representing the largest segment of the food retail sector, followed by open-air markets. Nonetheless, consolidation is slowly gaining momentum, as a few Italian and foreign operators are starting to expand their network of stores, particularly in the south of the country. Larger food retailers are starting to appeal to those consumers who are attracted by the convenience that one-stop shopping offers, and appreciate the wide range of products and additional services that larger retail formats provide [20].

Italian consumer acceptance of retailer brands is lower than in other European countries, including France, Spain, Germany and the United Kingdom. The discount store format remains quite marginal, but with the economic downturn has improved somewhat. In general, Italian consumers remain hesitant to shop at discount stores and purchase private label products. While small neighborhood shops and specialty stores are still the norm, Italian consumers are discovering the convenience of large supermarket and hypermarket outlets. Italian consumer purchasing habits place great value on the freshness and quality of products, therefore shopping several times a week versus other European countries where consumer patterns show a greater tendency towards once a weekly bulk purchasing.

The Italian population is aging and projected to decline in coming years. While living longer, Italians are having fewer children and marrying at a much later age. At the same time, continuing societal trends toward smaller families and an increasing number of women in the workforce are resulting in food retail outlets offering ready-made, ready-to-serve products and a wider range of products. However, contrary to trends across Europe, the majority of Italians still live in small cities and towns [21].

Currently, there are six major players in the Italian food retail and distribution sector: Coop Italia, Conad, Interdis, Carrefour, Auchan and SPAR. Despite the continued presence of traditional outlets, as well as increased competition from domestic and international retailers, these retailers occupy a dominant position in the market. Four of the leading players Coop Italia, Interdis, SPAR and Conad - exist as consortiums of smaller operators and owe some of their success to their detailed knowledge of local requirements and shoppers' preferences. Other major mass grocery retailers in terms of sales revenue include Esselunga and Gruppo Pam. The principal foreign investors are the major French retailers Carrefour, Auchan and Leclerc, as well as the German retailer Rewe and German discount chain Lidl. Through establishing joint ventures with local operators, Leclerc, Carrefour and Auchan have been able to build up a nationwide presence.

The Italian mass retail market has a value of $98.1 €$ Billion. The value is decreasing after the downturn of 2008. The total value is characterized by $6.6 \%$ by Hypermarket and supermarket, followed by department stores $5.9 \%$, large specialized stores $32.1 \%$, small traditional shops $39.2 \%$, and a group with Market stalls, ecommerce and door-to-door $16.1 \%$. In the Italian food retailing, the traditional stationary retail formats prevail in the market and account for the majority of the total revenue. Currently, the stationary retailing contributes the large majority to the sales volume in the Italian retail business. Over the past decade, convenience stores and especially discounters have experienced an increase in their market shares in the Italian food retailing. Traditional supermarkets, however, are losing market share at the benefit of two retail formats: market stall and department stores [22].

Since the store-based formats have been and still are the driving force in the food retailing sector for several decades, the non-stationary formats -especially Internet-based typeshave only played a minor role so far [23]. Moreover, nearly all large traditional retail chains have built up online shops, which, however, carry only general merchandise but no food in their assortments.

In the contemporary economic environment, ecommerce is the emerging business phenomenon in the world. A recent study by Casaleggio Ass. Reveals that the total size of Italy's consumer retail market was about $€ 14.4$ billion in 2010 and it is expected to grow to $€ 30.0$ billion by 2016 and to $€ 50.0$ billion by 2020 . The explosive growth in internet usage has more recently led to a corresponding growth in online business 
and e-commerce [24].

The common feature behind the top three categories consumers report purchasing online, including clothing/accessories (30 percent), electronics (54 percent) and games, toys and school supplies (37 percent), is that they contain items purchased occasionally, rather than items to be consumed in the immediate or near future. Research indicates that the more in-demand items are less popular among online shoppers, including personal care items (31 percent) and furniture/home decor (30 percent).

\section{THE RESEARCH}

In this paper a qualitative method, based on inductive multicase research [25], has been adopted to understand how groceries brands use Web to sell food goods. The reason of this methodological choice is that the aim of this analysis is neither verify a hypothesis nor falsify, confirm or modify an existing theory but better understand a still unknown phenomenon and explore it in depth. This methodology promotes the understanding of phenomena that are holistic, complex and that evolves over time [26] [27], such as that of the present study.

Even if the Italy's online grocery market is less developed than those in France and Germany, this paper aims to analyze the state of the art of food ecommerce in Italy. In particular, the study has two goals:

1. Identify the online commerce penetration in mass retail market for grocery food products.

2. Identify the delivery models adopted by every seller.

The paper started from the analysis of Federdistribuzione Internet site and the identification of Italian food retailers. Federdistribuzione is the lead trade association for the large and modern retail industry in Italy. It gets together and represents, at local, national and European level, large retail companies: hypermarkets, supermarkets, superettes, discounts, Department stores, large specialized stores. In the food grocery, in Italy there are about 150 different brands on the territory represented by 15.150 sales points (of which 7.450 in franchising) and 222.500 employees. After the gathering of all grocery brands, we visited the Internet sites to analyze:

- If the brand sells food products over Internet.

- Which are the areas where the service is available.

- The customer extra cost for the service.

- Which goods are sold over Internet.

- The delivery model.

For the previous last issue, literature presents three main model used by food ecommerce sites [28]:

- Home delivery. Home delivery managed from a central distribution center is a very common approach for pure online retailers that have not already invested into traditional retail stores. Traditional retailers entering the online business often chose the store based home delivery business model, which allows them to serve customers out of their established retail outlets. For example, Asda (UK) only pursues this approach [29].

- Click \& Collect. This business model offers consumers to pick up their pre-packed groceries from traditional retailer outlets. Some retailers have abandoned their store based home delivery service and they solely focuses on the pick-up service. This model is cheaper than the previous. As a store based model, consumers can order all SKUs offered in the respective retail outlet and may retrieve their groceries on the same day.

- Drive through. The drive-through lane works like fast-food or prescription pickup windows. These typically can serve only one shopper at a time, with others queuing up behind. Another possibility is to reserve a small number of parking spaces close to the main entrance for in-vehicle pickups. The customer orders by Web and book the time of picking. When he/she arrives to the retailer, a clerk puts goods in the customer's car.

\section{MAIN RESULTS}

The sample is composed of 129 Internet sites; the cases represent the entire peninsula.

The main facts are:

- 129 Internet sites visited - They represent 129 different grocery brands and they are present on the Italian territory with about 15.000 sale points.

- 14 brands have adopted the electronic commerce and now they are solding products over Internet

- 9 brands have not got an Internet site

- 107 brands use their Internet sites to present the company, promotions, special discounts, fidelity programs.

All the e-commerce sites deliver their products over a restricted area, in particular near the main metropolis in the North Italy (Milan and Turin).

The distribution model provided by the groceries is:

- Home delivery: 10 cases

- Click \& Collect: 9 cases

- Drive through: 3 cases

TABLE 1: DELIVERY MODELS

\begin{tabular}{lc}
\hline \hline Delivery Model & Number of cases \\
\hline Home Delivery & 10 \\
Click and Collect & 11 \\
Drive Through & 3 \\
Home Delivery And Click \& Collect & 5 \\
Home Delivery And Drive Through & 1 \\
Home Delivery, Click \& Collect And Drive Through & 2 \\
\hline \hline
\end{tabular}

Only Simply and Carrefour offer all the three ways to deliver goods. In every case, retailers pick goods in the points of sale, not in the distribution center. The average service cost is 6 Euro, but usually the delivery is free of charge if the total expense is greater than 40 Euro (minimum 39 Euro maximum 70). Delivery is very expensive if the value of the order is 40 Euro, its weight is $15 \%$. In the Home Delivery 
cases, customers can book the delivery. The service covers only a limited area around main hypermarkets or supermarkets. Simply, Carrefour and Esselunga are currently trialing their Drive Through format.

Probably, retailers in Italy, where labor costs are high, have seen some success with "click and drive" initiatives, and we expect growth will continue in the future, especially as retailers strengthen their online offering and framework. This solution is more convenient for the retailer because reduce logistics costs: load goods, transport and eventually the reverse logistics, in the case delivery failed.

Few food retailers offer online sales. One reason for this is the underdevelopment of the Italian e-commerce market. Nonstore retailing accounts for less than 3\% of total retail in Italy and only $15 \%$ of people shop online. Internet users who bought or ordered goods or services for private use over the internet in the previous 12 months are only $41 \%$ in Italy against the $66 \%$ of the European average [30]. The rise of $\mathrm{B} 2 \mathrm{C}$ e-commerce has brought challenges in retail logistics, especially in the physical distribution to the final customer. In traditional retail businesses, products are selected and taken home by the consumers from the local store at any time they want. In contrast, e-commerce enables consumers to select the products online and have them delivered to their doorstep [31]. Additional operations of order-picking, packaging and delivery have to be performed by the retailers which are expensive to carry out [32]. Thus, the responsibility for the fulfilment process has switched from the consumer to the retailer.

Probably, this situation will change soon because Amazon launched its Amazon Fresh grocery home-delivery service through its Prime Now service. For now, the fresh produce can only be ordered online by people living in the city of Milan and 34 municipalities in the back country. Shoppers in Italy can choose from 30 different fruits and vegetables in the app. These fresh produce items are available within a one or twohour delivery window from 8 AM to midnight. Amazon uses refrigerated vans to deliver products and avoid to break the cold chain [33].

\section{V.CONCLUSIONS}

Italy is a big and competitive retail markets worldwide. While there is a healthy competition among traditional brickand-mortar retailers (supermarkets and hard discount alike) a major competitive impact of online-food retailing does not exist to this point. While the Italian food retail sector is one of the largest in Europe, the sector's online/Internet provision for customers is far behind the United Kingdom (UK), France, and German. One factor that deters some Europeans from moving to the Internet for grocery shopping is a lack of quality assurance [34].

The preference for physical store shopping is probably even higher and steady in more "traditional" areas as Italy. One conclusion can be drawn from this: the value is mainly created in the physical shops, even it is captured online [35].

In the paper, the ecommerce for food goods is under- developed. Probably Italians are very concerned with the freshness of their produce and other consumables. Another reason is that delivery fees are still expensive, the average price is 6 Euro, the $15 \%$ in a 50 Euro expense when the Average Order Value (AOV) is 47 Euro in the brick and mortar retailers. The Average Order Value (AOV) is a metric that measures the average total of every order placed with a merchant over a defined period of time.

From the perspective of retailers, with ecommerce they have additional costs. In particular, for every order they must:

- Pick products from shelves and Pack goods. These actions require more personnel.

- Warrant the cold chain (if needed), in separate refrigerators.

- Deliver to the customer (in the Home Delivery case) with multi-temperature vans.

- Maintain goods in the right conditions until customer arrive (in the Click and Collect and Drive Through)

None brands deliver goods from the distribution centers (DC). DCs are not ready to pick few products for every order. Usually they prepare orders destined to the point of sale, large quantity and few points of delivery characterize every order. At moment, the distribution center must re-organize pick-\&pack processes and transportation (no big trucks but little vans).

Brick and Mortar retailers have developed ecommerce only around a few high density urban areas: delivery options are often limited to a few select areas throughout Italy.

In conclusion, the food online selling is in Italy at moment limited because:

- Customers are very concerned with the freshness;

- The delivery service is expensive

- Retailers are in front of new logistics costs and new operations

- Distribution centers need a new organization if they want to deliver in wide areas.

At the current point of time, the Italian online food retail market is in an early development phase. The question remains how successful could even a best practice operation become and would such an offering prove to be a financial success for the involved players? Hence, current traditional retailers have to decide between staying "traditional" and risking losing market shares in the long-term or access a potentially future promising market.

\section{REFERENCES}

[1] eMarketer, Worldwide Retail Ecommerce Sales: The eMarketer Forecast for 2016, online document, 2016.

[2] Nielsen, "E-commerce: Evolution or revolution in the fast-moving world?", The Nielsen Company, 2016.

[3] C. Seitz, "E-Grocery as New Innovative Distribution Channel in the German Food Retailing". In the Proceedings of the 2013 Active Citizenship by Knowledge Management \& Innovation: Management, Knowledge and Learning International Conference, 2013, pp: 125-133.

[4] ITU, "ICT Facts and Figures 2016", http://www.itu.int/en/Pages/default.aspx

[5] T. Hansen, Consumer adoption of online grocery buying: a discriminant analysis, International Journal of Retail \& Distribution Management, Vol. 33 No 2, 2005, pp. $101-121$. 
[6] T.S., Robertson, "The process of innovation and the diffusion of innovation", Journal of Marketing, Vol. 31, No.1, 1967, pp. 14 - 19.

[7] P.J., Danaher, G.W., Mullarkey, "Factors Affecting Online Advertising Recall: A Study of Students", Journal of Advertising Research, Vol. 43 No. 3, 2003, pp. $252-267$.

[8] R.L., Andrews, I.S., Currim, "Behavioural differences between consumers attracted to shopping online versus traditional supermarkets: implications for enterprise design and marketing strategy", International Journal Internet Marketing and Advertising, Vol.1, No. 1, 2004, pp.38-61

[9] A. Degeratu, A., Rangaswamy, J., Wu, "Consumer choice behavior in online and traditional supermarkets: the effects of brand name, price, and other search attributes", Working Paper, Smeal College of Business Administration, Pennsylvania State University, 1999.

[10] K., Ramus, N.A., Nielsen, "Online grocery retailing: what do consumers think?", Internet Research, Vol.15, No. 3, 2005, pp. 335 352.

[11] M., Brown, N., Pope, K., Voges, "Buying or browsing? An exploration of shopping orientations and online purchase intention", European Journal of Marketing, Vol. 37, No. 11/12, 2003, pp. 1666- 1684.

[12] M., Brengman, M., Geuens, B., Weijters, S., Smith, W., Swinyard, "Segmenting Internet Shoppers based on their Web-Usage-Related Lifestyle: A Cross-Cultural Validation", Journal of Business Research, Vol. 58, No. 1, 2005, pp. $79-88$.

[13] S. J., Barnes, H. H., Bauer, M. M., Newmann, F. Huber, "Segmenting cyberspace: a customer typology for the Internet", European Journal of Marketing, Vol. 41, No.1/2, 2007, pp. 71-93.

[14] A. J., Rohm, V., Swaminathan, "A Typology of Online Shoppers Based on Shopping Motivations", Journal of Business Research, Vol. 57, No. 7, 2004, pp. $748-758$.

[15] R. Gulati, J., Garino, "Get the Right Mix of Bricks \& Clicks", Harvard Business Review, Vol. 78, No.3, 2000, pp. 107 - 114.

[16] F. Cesaroni, D. Consoli, "Are Small Businesses Really Able to Take Advantage of Social Media?", The Electronic Journal of Knowledge Management, Vol. 13, No. 4, 2015, pp. 257 - 268.

[17] S. Mulpuru, "US eCommerce forecast: 2008 to 2012" Forrester Res. (January 18), 2008.

[18] J. Daniels, "Online grocery sales set to surge, grabbing 20 percent of market by 2025", CNBC, 30 Jan, 2017.

[19] C., Hand, F. Dall'Olmo, P. Harris, J. Singh, R. Rettie, "Online grocery shopping: the influence of situational factors", European Journal of Marketing, Vol.43, No. 9/10, 2009, pp. 1205 - 1219.

[20] D. Biasetti, "Italian Food Retail and Distribution Sector Report", Global Agricoltural Information Network, 2016.

[21] Istat,, Retail Trade, 2017, http://www.istat.it

[22] Federdistribuzione, "Mappa del Sistema distributivo Italiano", 2015, http://www.federdistribuzione.it/

[23] O., Passenheim, "Multi-Channel-Retailing: Entwicklung eines adaptiven und innovativen Konzeptansatzes" zur Integration des Internet als Absatzkanal im deutschen Lebensmitteleinzalhandel. München, Mering: Rainer Hampp Verlag. 2003.

[24] Casaleggio Ass., "E-commerce in Italy: numbers, trends and strategies", 2016, https://www.casaleggio.it/e-commerce/

[25] M., Miles, M., Huberman, "Qualitative Data Analysis: An Expanded Sourcebook", Second Edition. 1994, Beverly Hills: Sage.

[26] K.M., Eisenhardt, "Building theories from case study research", Academy of Management Review, Vol. 14, No. 4, 1989, pp. 532 - 550.

[27] H. F., Wolcott, "Transforming Qualitative Data: Description, Analysis, and Interpretation", Thousand Oaks, CA: Sage Publications. 1994.

[28] D. Werner, A., Sascha M., Ralph, F., Becker, "Concepts, challenges and market potential for online food retailing in Germany". Working Paper 108 of the Department of Business Policy and Logistics, University of Cologne, Cologne, 2011.

[29] N. Craven, "Tesco and Asda to launch 'ghost stores' in Ocado attack". Retrieved June 22, 2011, from http://www.dailymail.co.uk/money/article-1299245/Tesco-Asdalaunch-ghost-stores-Ocado-attack.html.

[30] Eurostat, "E-commerce statistics for individuals", Eurostat 2017.

[31] Y. Xing, D.B., Grant, "Developing a framework for measuring physical distribution service quality of multi-channel and pure player internet retailers", International Journal of Retail \& Distribution Management
Vol. 34, No. 4/5, 2006, pp. $278-289$.

[32] V. Kämäräinen, M., Punakivi, "Developing Cost-effective Operations for the e- Grocery Supply Chain", International Journal of Logistics: Research and Applications, Vol.5, No. 3, 2002, pp. 286 - 298.

[33] EcommerceNews, 2016, "Amazon now sells fresh produce in Italy", https://ecommercenews.eu/amazon-now-sells-fresh-produce-italy/

[34] RetailNet Group, "The rise of the online grocery market: Continental Europe". 2011, http://www.retailnetgroup.com/

[35] M., Brown, M., Moriarty, A., Mendoza-Pena, "On Solid Ground: Brick-and-Mortar is the Foundation of the Omnichannel Retailing", A.T.Kearney, 2013. 